\title{
Effect of inhaled frusemide and oral indomethacin on the airway response to hypertonic saline challenge in asthmatic subjects
}

\author{
Leanne T Rodwell, Sandra D Anderson, Joanne Spring, Safaa Mohamed, J Paul Seale
}

\begin{abstract}
Background - Inhaled frusemide inhibits airway narrowing and causes a transient increase in forced expiratory volume in one second $\left(\mathrm{FEV}_{1}\right)$ during hypertonic saline challenge. This inhibitory effect could be secondary to prostaglandin release during challenge. The involvement of prostaglandins in the inhibitory action of frusemide during challenge with $4.5 \%$ $\mathrm{NaCl}$ was investigated by premedicating with indomethacin, a prostaglandin synthetase inhibitor.
\end{abstract}

Methods - Fourteen asthmatic subjects (eight women) aged 26.6 (range 18-56) years participated in a double blind, placebo controlled, crossover study. The subjects attended five times and inhaled $4.5 \%$ $\mathrm{NaCl}$ for $0.5,0.75,1,1.5,2,4,8,8$, and 8 minutes, or part thereof, or until a provocative dose causing a $20 \%$ fall in $\mathrm{FEV}_{1}$ $\left(\mathbf{P D}_{20} \mathrm{FEV}_{1}\right)$ was recorded. Indomethacin (100 mg/day) or placebo were taken three days before all visits, except control day. The $\mathrm{FEV}_{1}$ was measured and frusemide (38.0 (6.4) $\mathrm{mg}, \mathrm{pH}=9)$ or vehicle $(0.9 \%$ $\mathrm{NaCl}, \mathrm{pH}=9$ ) were inhaled 10 minutes before the challenge. Bronchodilation was calculated as the percentage rise in $\mathrm{FEV}_{1}$ from the prechallenge $F E V_{1}$ to the highest $\mathrm{FEV}_{1}$ recorded during the challenge. Results - Frusemide caused a fold increase in $\mathbf{P D}_{20} \mathrm{FEV}_{1}$ compared with the vehicle which was similar in the presence of both indomethacin and placebo (3.7 (95\% CI 2.0 to 7.3$)$ versus $3.3(2.0$ to 5.4$)$ ). Frusemide, but not vehicle, also caused a transient percentage rise in $\mathrm{FEV}_{1}$ during challenge with $4.5 \% \mathrm{NaCl}$ which was not blocked by indomethacin $(3.6 \%$ (1.2 to $6.0)$ ) or placebo $(3.1 \%$ (1.0 to 5.2$))$.

Conclusions - Inhaled frusemide inhibited airway narrowing and caused a transient increase in $\mathrm{FEV}_{1}$ during challenge with $4.5 \% \mathrm{NaCl}$. These effects were not blocked by indomethacin, which suggests that the inhibitory action of frusemide is not secondary to prostaglandin release.

(Thorax 1997;52:59-66)

Keywords: asthma, hypertonic saline, indomethacin, frusemide, bronchial responsiveness.

Inhaled frusemide inhibits the airway response to challenge with hypertonic saline in asthmatic subjects ${ }^{12}$ by a mechanism which may involve the blockade of chloride channels at several sites in the airways including mast cells, epithelial cells, and nerves. ${ }^{2-4}$ The inhibitory effect of frusemide on hypertonic saline challenge could also be attributed in part to its potential to release prostaglandin $\mathrm{E}_{2}\left(\mathrm{PGE}_{2}\right)^{56}$ which may indirectly relax airway smooth muscle. ${ }^{7} \mathrm{~A}$ hypertonic stimulus alone also has the potential to release $\mathrm{PGE}_{2}$ from epithelial cells. ${ }^{8}$ The combination of frusemide and a hypertonic stimulus may enhance the release of $\mathrm{PGE}_{2}$, resulting in the transient bronchodilation observed by Rodwell and colleagues ${ }^{2}$ in six of the 11 asthmatic subjects they studied.

There are several reasons why $\mathrm{PGE}_{2}$ may be the cause of the transient bronchodilation: (1) human airway epithelium releases $\mathrm{PGE}_{2}{ }^{9}{ }^{10}$ (2) frusemide stimulates $\mathrm{PGE}_{2}$ production; ${ }^{56}$ (3) the protective effect of inhaled frusemide against airway narrowing caused by exercise in asthmatic subjects is inhibited by indomethacin, ${ }^{11}$ a drug which inhibits the synthesis of $\mathrm{PGE}_{2}$; and (4) when $\mathrm{PGE}_{2}$ is inhaled by normal subjects five minutes before histamine challenge there is a delay in airway narrowing ${ }^{12}$ similar to the delay observed during challenge with $4.5 \% \mathrm{NaCl}$ after inhaling frusemide. ${ }^{2}$

If $\mathrm{PGE}_{2}$ is responsible for the transient bronchodilation and the "braking effect" on airway narrowing caused by hypertonic saline challenge, then indomethacin, a cyclo-oxygenase inhibitor, ${ }^{13}$ taken before frusemide inhalation should block the transient bronchodilation and the delay in airway narrowing.

The aim of this study was to investigate the role of prostaglandins in the transient bronchodilation caused by frusemide during challenge with $4.5 \% \mathrm{NaCl}$ inhalation in asthmatic subjects.

\section{Methods}

SUBJECTS

Fourteen asthmatic subjects (eight women) with a mean age (range) of $26.6(18-56)$ years attended the respiratory investigation unit on five occasions with at least four days between visits. Subjects had a baseline forced exhibitory volume in one second $\left(\mathrm{FEV}_{1}\right)$ of $62-90 \%$ of the predicted value ${ }^{14}$ and/or a history of a greater than $10 \%$ reversibility in $\mathrm{FEV}_{1}$ after inhaling a $\beta_{2}$ adrenoceptor agonist. To be eligible for the study subjects had to record at least a $20 \%$ fall in $\mathrm{FEV}_{1}$ after inhaling $4.5 \%$ $\mathrm{NaCl}$ on the control day. Subjects were excluded from the study if they had a history of respiratory symptoms after taking non-steroidal 
Table 1 Anthropometric details, prechallenge $F E V_{1}, P D_{20} F E V_{1}$ on control day, asthma medications, dose of inhaled corticosteroids and time on this dose $(n=14)$

\begin{tabular}{|c|c|c|c|c|c|c|c|}
\hline Subject no. & Sex & Age (years) & $\begin{array}{l}F E V_{t} \\
\text { control } \\
\text { (\% pred) }\end{array}$ & $\begin{array}{l}P D_{20} F E V_{1} \\
\text { control } \\
\text { (ml) }\end{array}$ & $\begin{array}{l}\text { Asthma } \\
\text { medication }\end{array}$ & $\begin{array}{l}\text { Dose of } \\
\text { ICS } \\
(\mu g)\end{array}$ & $\begin{array}{l}\text { Time on } \\
\text { this dose } \\
\text { (months) }\end{array}$ \\
\hline 1 & M & 27 & 63.7 & 3.7 & S,BUD & 1000 & 3 \\
\hline 2 & $\mathrm{~F}$ & 19 & 82.2 & 6.3 & $\mathrm{~S}$ & - & - \\
\hline 3 & $M$ & 19 & 97.4 & 3.3 & TO & - & - \\
\hline 4 & $\mathrm{~F}$ & 19 & 87.2 & 8.5 & $S, B D P$ & 400 & 4 \\
\hline 5 & M & 53 & 70.0 & 5.0 & S & - & - \\
\hline 6 & $\mathrm{~F}$ & 56 & 88.0 & 2.9 & S & - & - \\
\hline 7 & $\mathrm{~F}$ & 20 & 86.3 & 8.6 & S,BUD & 800 & 10 \\
\hline 8 & $M$ & 23 & 82.9 & 4.4 & S,BUD & 2400 & 24 \\
\hline 9 & M & 25 & 92.5 & 11.2 & $\mathrm{~S}$ & - & - \\
\hline 10 & $\mathrm{~F}$ & 24 & 79.2 & 1.0 & S & - & - \\
\hline 11 & $\mathrm{~F}$ & 18 & 62.7 & 1.0 & $\mathrm{~S}$ & - & - \\
\hline 12 & $\mathrm{~F}$ & 18 & 96.3 & 5.7 & S,BUD & 2000 & 4 \\
\hline 13 & $\mathrm{~F}$ & 21 & 85.4 & 1.1 & $\mathrm{~S}, \mathrm{BDP}$ & 400 & 6 \\
\hline 14 & M & 30 & 86.0 & 21.1 & S & - & - \\
\hline Mean & & 26.6 & 82.8 (SE 2.9) & $4.2 *(95 \%$ & 2.5 to 7.1$)$ & & \\
\hline
\end{tabular}

$\mathrm{FEV}_{1}=$ forced expiratory volume in one second; $\mathrm{PD}_{20} \mathrm{FEV}_{1}=$ dose of $4.5 \% \mathrm{NaCl}$ aerosol $(\mathrm{ml})$ causing a $20 \%$ fall in $\mathrm{FEV}$; $\mathrm{ICS}_{=}$ inhaled corticosteroids; $\mathrm{S}=$ salbutamol; $\mathrm{BUD}=$ budesonide; $\mathrm{TO}=$ terbutaline oral; $\mathrm{BDP}=$ beclomethasone dipropionate. Only one subject (no. 3) was taking oral asthma medication.

* Geometric mean.

anti-inflammatory drugs (NSAIDs) or if they had a history of gastric ulcers. Anthropometric details, the $\mathrm{FEV}_{1}$ measured as a percentage of the predicted value on the control day, the dose of saline required to provoke a fall in $\mathrm{FEV}_{1}$ of $20 \%\left(\mathrm{PD}_{20} \mathrm{FEV}_{1}, \mathrm{ml}\right)$ on the control day, and regular asthma medications are given in table 1 .

Beta $_{2}$ adrenoceptor agonists were withheld for at least six hours before the $4.5 \% \mathrm{NaCl}$ challenge. Six of the 14 subjects were taking inhaled corticosteroids on a daily basis for at least three months before the commencement of the study and the dose remained unchanged for the duration of the study. All subjects were atopic, having positive skin reactions to one or more of eight common allergens. Subjects were asked about recent symptoms of wheeze or dyspnoea. If an increase in these symptoms occurred in the previous 24 hours then testing did not proceed. No subject had a chest infection during the four weeks prior to the control visit.

The protocol was fully explained and written informed consent was obtained from each subject. The study was approved by the Central Sydney Health Area ethics committee.

FRUSEMIDE AND ITS VEHICLE

Ampoules of frusemide (Lasix; Hoechst AG, Germany), each containing $20 \mathrm{mg}$ frusemide in $2 \mathrm{ml}(10 \mathrm{mg} / \mathrm{ml})$, with a $\mathrm{pH}$ of 9 , were used in the study. The vehicle was $0.9 \% \mathrm{NaCl}$ adjusted daily by the investigator to a $\mathrm{pH}$ of $8.9-9.2$ by adding sodium hydroxide dissolved in $0.9 \%$ $\mathrm{NaCl}$. A pH meter (Radiometer PHM 62, Copenhagen, Denmark) was used to measure the $\mathrm{pH}$ of the frusemide and its vehicle. The osmolality of the frusemide and its vehicle was 303 mosmol as measured by freezing point depression (Advanced Cryomatic Osmometer, Model Advanced Instruments, Massachusetts, USA). Once the osmolality of the vehicle solution was adjusted, both the frusemide and the vehicle were drawn up in separate $10 \mathrm{ml}$ syringes and given to a pharmacist for assignment according to a randomisation code.
One syringe with either the frusemide or vehicle was then returned to the investigator to administer to the subject. This was a double blind, vehicle controlled, randomised, crossover study.

\section{DELIVERY OF AEROSOL FRUSEMIDE AND ITS} VEHICLE

The Fisoneb ultrasonic nebuliser (Fisons Corporation, Rochester, New York, USA) producing a dense aerosol with a mass median aerodynamic diameter of $4.7 \mu \mathrm{m}$ was used to deliver both the frusemide and the vehicle.

In order to give a dose of frusemide similar to that used in a previous study, ${ }^{2} 6 \mathrm{ml}$ of frusemide or vehicle was placed in the Fisoneb. Subjects inhaled the aerosols for 7-9 minutes via a mouthpiece while wearing nose clips. The unit was weighed (Sartorius Analytic, Gottingen, Germany) before and after nebulisation and a stopper placed in the output hole during weighing to reduce loss of volume by evaporation. The difference in weight change was recorded as the amount of frusemide or vehicle nebulised. The mean (SD) amount of frusemide nebulised for the challenge was 38.0 (6.4) $\mathrm{mg}(\mathrm{n}=26)$. On two occasions subjects salivated profusely back into the Fisoneb during nebulisation so these values were not included in the calculation of the mean dose of frusemide delivered.

INDOMETHACIN AND ITS PLACEBO

Subjects ingested $50 \mathrm{mg}$ of indomethacin (Arthrexin, Alphapharm, Australia) twice a day $(100 \mathrm{mg} /$ day) or a placebo (glucose powder in an identical capsule) for three days before each challenge visit.

Subjects were given 12 capsules of either $25 \mathrm{mg}$ indomethacin or placebo at the end of the control day and visits 1,2 , and 3 and instructed to take two capsules twice a day in the morning and at night for three days before visits $1,2,3$, and 4 . The last two capsules were to be taken approximately 1.5 hours before coming to the laboratory. 
AIRWAY SENSITIVITY TO INDOMETHACIN

All subjects were assessed for airway sensitivity to oral indomethacin ${ }^{15}$ on the control visit. After recording at least a $20 \%$ fall in $\mathrm{FEV}_{1}$ to $4.5 \% \mathrm{NaCl}$ challenge on the control day subjects recovered spontaneously over a one hour period after challenge. They were given either a peak flow meter (Clement Clarke International Ltd, Harlow, Essex, UK) or an airflow meter ${ }^{16}$ and instructed how to measure and record their expiratory flow rates. The flow rate was measured before ingesting two $25 \mathrm{mg}$ capsules $(50 \mathrm{mg})$ of indomethacin and every hour for six hours after ingesting the capsules. The first and second hourly measurements were taken in the laboratory with subsequent measurements being carried out at home. Subjects were excluded from the study if there was a greater than $21 \%$ variability from the expiratory flow rate measured before indomethacin.

MEASUREMENT OF THROMBOXANE $\mathrm{B}_{2}\left(\mathrm{TXB}_{2}\right)$

PLASMA LEVELS

The extent to which indomethacin inhibited cyclo-oxygenase activity was determined indirectly by measuring plasma levels of thromboxane $\mathrm{B}_{2}\left(\mathrm{TXB}_{2}\right)$ by radioimmunoassay (RIA). $\mathrm{TXB}_{2}$ was measured because it is a stable metabolite of arachadonic acid and is found in large quantities in plasma.

COLLECTION AND PROCESSING OF VENOUS BLOOD SAMPLES

On visits $1,2,3$, and 4 a $10 \mathrm{ml}$ venous blood sample was taken from the forearm of each subject ${ }^{17}$ in the 10 minute period after the $4.5 \%$ $\mathrm{NaCl}$ challenge. The blood was immediately transferred into a $10 \mathrm{ml}$ prechilled siliconised glass test tube coated with a solution of $4.5 \mathrm{mM}$ EDTA and $5 \mu \mathrm{g} / \mathrm{ml}$ of indomethacin dissolved in ethanol. The tube was capped and gently inverted several times to ensure adequate mixing of the blood sample, EDTA, and indomethacin. This sample was immediately placed in ice chips and within 10 minutes was centrifuged for 10 minutes at $2500 \mathrm{rpm}$ at $4^{\circ} \mathrm{C}$. The plasma from the sample was then pipetted into two $2.5 \mathrm{ml}$ cryogenic tubes and "snap frozen" in liquid nitrogen for approximately one minute. The frozen sample was removed from the liquid nitrogen and stored in a deep freeze at $-80^{\circ} \mathrm{C}$. At a later date the plasma samples were thawed and plasma levels of $\mathrm{TXB}_{2}$ were measured using RIA (NEN Inc, Biomedical Products Department, Boston, Massachusetts, USA).

CHALLENGE WITH 4.5\% NACL AEROSOL

The protocol used to perform the $4.5 \% \mathrm{NaCl}$ challenge was similar to that described by Rodwell and colleagues, ${ }^{2}$ although the initial inhalation periods were of a shorter duration in order to optimise the detection of changes in $\mathrm{FEV}_{1}$ during the initial stage of the challenge. Subjects inhaled the challenge aerosol for 0.5 minutes, waited one minute, then spirometric tests were performed. If there was a $20 \%$ fall in $\mathrm{FEV}_{1}$ from the baseline value the challenge was stopped and the subject included in the study. If a $20 \%$ fall was not recorded the challenge continued for further intervals of 0.75 , $1.0,1.5,2.0,4.0,8.0,8.0$, and 8.0 minutes, or part thereof, or until a fall in $\mathrm{FEV}_{1}$ of at least $20 \%$ was recorded.

\section{STUDY DESIGN}

Subjects were required to attend the laboratory on five occasions with a minimum of four days separating all visits because indomethacin has a half life of $2-11$ hours. ${ }^{18}$ Drug administration was randomised so that each subject received either indomethacin and frusemide/vehicle or placebo and frusemide/vehicle.

CONTROL DAY

Eligibility for the study was assessed on the control day. On arrival at the laboratory spirometric tests (Minato Autospirometer AS500, Osaka, Japan) were performed in triplicate and then repeated 10 minutes later. If there was a less than $10 \%$ variation in the $\mathrm{FEV}_{1}$ over 10 minutes the airways were considered stable and the $4.5 \% \mathrm{NaCl}$ challenge was performed. When a $20 \%$ fall from baseline $\mathrm{FEV}_{1}$ was recorded the challenge was stopped and the $\mathrm{PD}_{20} \mathrm{FEV}_{1}$ (ml) calculated. Lung function spontaneously recovered over the following 60 minutes and then airway sensitivity to $50 \mathrm{mg}$ of oral indomethacin was assessed by measuring expiratory flow rates over the following six hours.

VISITS $1,2,3$, AND 4

On arrival at the laboratory spirometric tests were performed in triplicate and repeated 10 minutes later. If there was less than $10 \%$ variation in these measurements subjects inhaled the frusemide or its vehicle via a Fisoneb ultrasonic nebuliser. Ten minutes later the spirometric tests were repeated in triplicate and the highest recorded $\mathrm{FEV}_{1}$ used as the baseline $\mathrm{FEV}_{1}$ for the $4.5 \% \mathrm{NaCl}$ challenge. The $4.5 \%$ $\mathrm{NaCl}$ challenge was stopped when either a fall of more than $20 \%$ in $\mathrm{FEV}_{1}$ was recorded or the last dose of $4.5 \% \mathrm{NaCl}$ aerosol was nebulised. A venous blood sample was taken for the measurement of $\mathrm{TXB}_{2}$ plasma levels in the first 10 minutes after the $4.5 \% \mathrm{NaCl}$ challenge.

Before leaving the laboratory subjects were given either the indomethacin or placebo capsules for the next visit. They were instructed to take their indomethacin 1.5 hours before coming to the laboratory as peak plasma concentrations are reached approximately two hours after taking indomethacin. ${ }^{18}$

ANALYSIS OF DATA

Effect of inhaled frusemide and its vehicle on baseline $\mathrm{FEV}_{1}$ prechallenge

The effect of inhaling frusemide or its vehicle on baseline lung function was assessed by calculating the difference in $\mathrm{FEV}_{1}$ before and 10 minutes after inhaling these aerosols. This was 
calculated on the days the placebo for indomethacin was given.

$\mathrm{PD}_{20} \mathrm{FEV}_{1}$ to $4.5 \% \mathrm{NaCl}$ challenge

The provocative dose of $4.5 \% \mathrm{NaCl}(\mathrm{ml})$ causing a $20 \%$ fall from the baseline $\mathrm{FEV}_{1}\left(\mathrm{PD}_{20}\right.$ $\mathrm{FEV}_{1}$ ) was calculated and reported as the geometric mean with $95 \%$ confidence intervals. Changes in $\mathrm{PD}_{20} \mathrm{FEV}_{1}$ between study days were reported as the fold change with $95 \%$ confidence intervals.

Percentage rise in $F E V_{1}$ during challenge

The transient bronchodilation or the percentage rise in $\mathrm{FEV}_{1}$ from the baseline prechallenge $\mathrm{FEV}_{1}$ during challenge (\% rise) was calculated by subtracting the highest $\mathrm{FEV}_{1}$ (l) recorded during challenge from the prechallenge $\mathrm{FEV}_{1}$ (l) and expressing this difference as a percentage of the prechallenge $\mathrm{FEV}_{1}$ (1).

\section{Maximum percentage rise in $F E V_{1}$ during challenge}

The maximum percentage rise recorded on the two days frusemide was inhaled was calculated. At the greater of the these two values the cumulative dose of $4.5 \% \mathrm{NaCl}(\mathrm{ml})$ was recorded, thus giving an indication when the maximum percentage rise in $\mathrm{FEV}_{1}$ occurs during challenge. The significance of the maximum percentage rise in $\mathrm{FEV}_{1}$ during challenge with $4.5 \% \mathrm{NaCl}$ was then tested by comparing the percentage rise on the frusemide day with the percentage rise on the vehicle day at the same delivered dose of $4.5 \% \mathrm{NaCl}$. For example, if the maximum percentage rise in $\mathrm{FEV}_{1}$ occurred after $5 \mathrm{ml}$ on the placebo/frusemide day, then it was compared with the corresponding percentage rise in $\mathrm{FEV}_{1}$ at $5 \mathrm{ml}$ on the placebo/ vehicle day. The comparison of the maximum percentage rise between inhaled frusemide and vehicle was therefore performed only in the presence of indomethacin or placebo.

Differences in plasma $\mathrm{TXB}_{2}$ levels

Plasma levels of $\mathrm{TXB}_{2}(\mathrm{pg} / \mathrm{ml}$ plasma) were compared between the indomethacin and the placebo study days.

Relationship between $\mathrm{TXB}_{2}$ levels and percentage rise in FEV

The mean difference in plasma $\mathrm{TXB}_{2}$ levels on the placebo/vehicle and indomethacin/frusemide days and the mean difference in the percentage rise in $\mathrm{FEV}_{1}$ on the placebo/vehicle and indomethacin/frusemide days were calculated. A Spearman's rank correlation was then performed on these calculated differences.

STATISTICAL ANALYSIS

Data are presented as mean with $95 \%$ confidence intervals or the mean and its range. The $\mathrm{PD}_{20} \mathrm{FEV}_{1}$ (ml) to $4.5 \% \mathrm{NaCl}$ challenge is summarised as the geometric mean with $95 \%$ confidence intervals. A Student's paired $t$ test was used to test differences between paired mean data and a Pearson's or Spearman's correlation test for relationships between variables. Differences were considered significant at $\mathrm{p}<0.05$.

\section{Results}

FEV $_{1}$ ON ARRIVAL: CONTROL DAY AND VISITS 1-4 On arrival at the laboratory there was less than a $20 \%$ difference in the $\mathrm{FEV}_{1}$ between the control day and subsequent visits.

EFFECT OF INHALED FRUSEMIDE AND ITS VEHICLE ON BASELINE $\mathrm{FEV}_{1}$ : PRECHALLENGE

There was a small increase of 0.061 ( 0 to 0.12 ) from baseline $\mathrm{FEV}_{1} 10$ minutes after inhaling frusemide and a decrease of $0.071(-0.13$ to $-0.01)$ after inhaling the vehicle $(p=0.03$, $\mathrm{n}=14$ ). These changes were considered not clinically significant.

EFFECT ON PD 20 FEV $_{1}$ OF CHALLENGE WITH $4.5 \%$ NACL

On the days frusemide was inhaled there was a significant increase in the $\mathrm{PD}_{20} \mathrm{FEV}_{1}$ to $4.5 \%$ $\mathrm{NaCl}$ challenge. In the presence of indomethacin the mean $\mathrm{PD}_{20} \mathrm{FEV}_{1}$ increased from $5.4 \mathrm{ml}$ (2.9 to 9.9$)$ after inhaling the vehicle to $20.2 \mathrm{ml}(14.5$ to 28.4$)$ after inhaling frusemide $(\mathrm{p}<0.001, \mathrm{n}=14)$, which represented a $3.7(2.0$ to 7.3) fold increase. In the presence of placebo the $\mathrm{PD}_{20} \mathrm{FEV}_{1}$ increased from $4.9 \mathrm{ml}$ (2.5 to 9.6) after inhaling the vehicle to $16.3 \mathrm{ml}(11.2$ to 23.7) after inhaling frusemide $(\mathrm{p}<0.001, \mathrm{n}=$ 14 ), a 3.3 (2.0 to 5.4) fold increase.

The fold increase in $\mathrm{PD}_{20} \mathrm{FEV}_{1}$ caused by frusemide was similar in the presence of indomethacin and placebo (3.7 (2.0 to 7.3 ) versus 3.3 (2.0 to 5.4$) ; \mathrm{p}=0.61, \mathrm{n}=14)$. Indomethacin therefore had no effect on the increase in $\mathrm{PD}_{20} \mathrm{FEV}_{1}$ caused by frusemide.

When the vehicle was inhaled there was no significant difference in the $\mathrm{PD}_{20} \mathrm{FEV}_{1}$ between the indomethacin and placebo days with the mean fold difference being 0.9 (0.6 to 1.4 ); $\mathrm{p}=0.66(\mathrm{n}=14)$.

There was a range of asthma severity ${ }^{19}$ within the group (table 1) with the mean $\mathrm{PD}_{20} \mathrm{FEV}_{1}$ being $4.2 \mathrm{ml}$ (2.5 to 7.1 ) which is considered to be in the moderate range. Three subjects had severe asthma $\left(\mathrm{PD}_{20} \mathrm{FEV}_{1} \leq 2 \mathrm{ml}\right)$, six had moderate asthma $\left(\mathrm{PD}_{20} \mathrm{FEV}_{1}>2 \mathrm{ml}\right.$ and $\leq 6 \mathrm{ml})$, and five had mild asthma $\left(\mathrm{PD}_{20} \mathrm{FEV}\right.$ $>6 \mathrm{ml}$ ). Two subjects (11 and 13) contracted a mild chest infection after visit 3 and therefore there was a period of 28 and 29 days, respectively, between visits 3 and 4 .

PERCENTAGE RISE IN FEV 1 DURING CHALLENGE Frusemide, when inhaled by asthmatic subjects before challenge with $4.5 \% \mathrm{NaCl}$, caused a transient rise in $\mathrm{FEV}_{1}$ which was not blocked by indomethacin or its placebo (3.6\% (1.2 to 6.0 ) versus $3.1 \%(1.0$ to 5.2$)$ ) with a mean 
difference of $0.6 \%$ ( -1.7 to 2.9$) ; \mathrm{p}=0.60$ ( $\mathrm{n}=$ 14). When the vehicle was inhaled there was a fall from the baseline $\mathrm{FEV}_{1}$ during challenge in the presence of indomethacin and its placebo $(-4.8 \%(-8.2$ to -1.5$)$ versus $-2.2(-6.9$ to 2.5$)$ ) with a mean difference of $-2.6 \%$ $(-6.4$ to 1.2$) ; \mathrm{p}=0.19(\mathrm{n}=14)$.

There was an inverse relationship between the prechallenge $\mathrm{FEV}_{1}$ recorded after subjects inhaled the frusemide and the percentage rise in $\mathrm{FEV}_{1}$ recorded during challenge $(r=-0.469$, $\mathrm{p}<0.02, \mathrm{n}=28)$. This suggests that the lower the prechallenge $\mathrm{FEV}_{1}$ the greater is the percentage rise during the challenge.

\section{MAXIMUM PERCENTAGE RISE IN FEV 1 DURING} CHALLENGE

The mean (95\% CI) highest percentage rise in $\mathrm{FEV}_{1}$ during $4.5 \% \mathrm{NaCl}$ challenge was $4.9 \%$ (2.6 to 7.1 ) which occurred after (geometric mean with $95 \%$ CI) $1.96 \mathrm{ml}$ (1.1 to 3.5$)$ of $4.5 \% \mathrm{NaCl}$ had been nebulised. The maximum percentage rise occurred on the placebo/frusemide day in nine of the 14 subjects and on the indomethacin/frusemide day in the remaining five subjects. At the common nebulised dose of saline $(1.96 \mathrm{ml}$ (1.1 to 3.34)) there was a $4.9 \%$ (2.6 to 7.1$)$ rise from baseline $\mathrm{FEV}_{1}$ on the frusemide day compared with a fall of $-9.6 \%(-13.8$ to -5.4$)$ from baseline $\mathrm{FEV}_{1}$ on the corresponding vehicle day. The mean difference between the rise from baseline $\mathrm{FEV}_{1}$ in the presence of frusemide and the fall from baseline in the presence of vehicle was $14.5 \%$ (9.4 to 19.6$) ; \mathrm{p}<0.001(\mathrm{n}=14)$.

PLASMA $\mathrm{TXB}_{2}$ LEVELS

Plasma levels of $\mathrm{TXB}_{2}$ measured in the presence of indomethacin were lower than the levels measured on the placebo day with the mean difference being $154.8 \mathrm{pg} / \mathrm{ml}$ (62.5 to 247.1 ); $\mathrm{p}=0.002(\mathrm{n}=28)$. The results suggest that indomethacin inhibited but did not completely block the formation of plasma $\mathrm{TXB}_{2}$.

RELATIONSHIP BETWEEN TXB 2 LEVELS AND PERCENTAGE RISE IN FEV Indomethacin significantly reduced plasma $\mathrm{TXB}_{2}$ levels compared with its placebo. The mean difference in plasma $\mathrm{TXB}_{2}$ levels between the indomethacin and placebo days was $73 \mathrm{pg} /$ $\mathrm{ml}(17.0$ to 129.4$) ; \mathrm{p}=0.01(\mathrm{n}=14)$. The percentage rise during challenge with $4.5 \% \mathrm{NaCl}$ was greater in the presence of frusemide than its vehicle with the mean difference being $-5.8 \%$ $(-11.2$ to -0.4$) ; \mathrm{p}=0.04(\mathrm{n}=14)$. There was, however, no significant correlation between the reduction in plasma $\mathrm{TXB}_{2}$ levels and the effect of frusemide on lung function during challenge $\left(r_{\mathrm{S}}=0.13 ; \mathrm{p}=\mathrm{NS}, \mathrm{n}=14\right)$.

Individual dose-response curves for the five study days for the 14 subjects who participated in this study are shown in fig 1.

\section{Discussion}

The results show that the transient bronchodilation caused by inhaled frusemide during the initial stages of airway challenges ${ }^{21920}$ has been reproduced in this study and that indomethacin had no effect on the decrease in airway sensitivity to $4.5 \% \mathrm{NaCl}$ challenge caused by frusemide. It is therefore unlikely that prostaglandins are involved in the transient bronchodilation and the decrease in airway sensitivity to $4.5 \% \mathrm{NaCl}$ challenge as indomethacin, a prostaglandin synthetase inhibitor, is not effective in inhibiting these responses. These findings are supported by the results of studies performed in human nasal mucosa ${ }^{21}$ where frusemide did not cause an increase in $\mathrm{PGE}_{2}$ levels.

The significant bronchodilation during challenge observed in the presence of approximately $40 \mathrm{mg}$ frusemide occurred after $2 \mathrm{ml}$ of $4.5 \%$ $\mathrm{NaCl}$ had been nebulised. This bronchodilation during challenge has not been described in previous studies where smaller doses of frusemide have been nebulised. ${ }^{22-27}$ With the inhalation of larger doses of frusemide $(40-80 \mathrm{mg})$ bronchodilation has been observed. ${ }^{2028}$ Thus, the protective effect of frusemide which we observed against airway challenge may be partly attributable to its bronchodilating action, but only at higher doses.

This is the first study to investigate the transient bronchodilation observed in the presence of frusemide during $4.5 \% \mathrm{NaCl}$ challenge in asthmatic subjects. During exercise challenge a single maximum stimulus dehydrates the airways and a dose-response curve cannot be constructed. Subtle changes in lung function would therefore be missed during exercise challenge. Also, if subjects were at their best lung function before the start of challenge then it is unlikely that bronchodilation would be observed during the challenge. All subjects in the present study were either at less than $90 \%$ of their predicted $\mathrm{FEV}_{1}$ or were known to have at least a $10 \%$ increase in $\mathrm{FEV}_{1}$ after inhaling a bronchodilator. Airways obstruction before challenge maximises the opportunity to observe transient bronchodilation during challenge. In fact, there was an inverse correlation between lung function and the transient bronchodilation caused by frusemide - that is, the lower the prechallenge lung function the greater the percentage rise in $\mathrm{FEV}_{1}$ during challenge.

Inhaled frusemide also caused a small increase in the prechallenge $\mathrm{FEV}_{1}$ and an increase in the $\mathrm{PD}_{20} \mathrm{FEV}_{1}$ to $4.5 \% \mathrm{NaCl}$ aerosol, both of which were unaffected by premedication with indomethacin.

This study shows that indomethacin has no effect on the decrease in airway sensitivity to $4.5 \% \mathrm{NaCl}$ challenge caused by frusemide. The 3.3-fold decrease in $\mathrm{PD}_{20} \mathrm{FEV}_{1}$ on the placebo day was not significantly different from the 3.7-fold decrease in $\mathrm{PD}_{20} \mathrm{FEV}_{1}$ on the indomethacin day. Plasma $\mathrm{TXB}_{2}$ levels were significantly lower on the days of indomethacin administration, indicating that subjects had taken their capsules as instructed.

We selected a dose of $100 \mathrm{mg} /$ day indomethacin because it blocks refractoriness to 

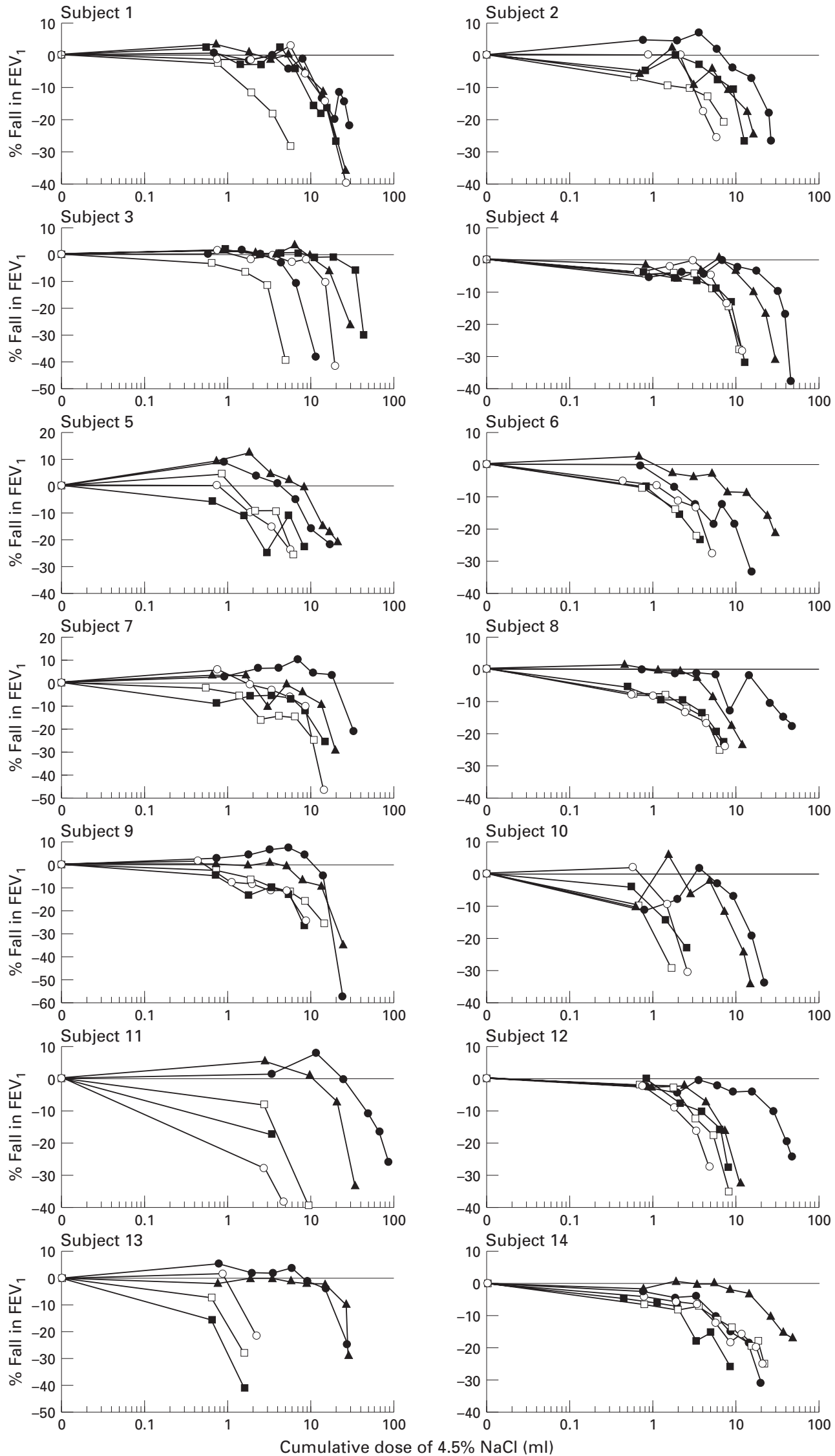

Figure 1 Individual dose-response curves representing the percentage fall from the prechallenge FEV $V_{1}$ on the control and four study days for the 14 subjects participating in the study. $\square=$ control day; $\mathbf{O}=$ indomethacin/frusemide day; $\square=$ indomethacin/vehicle day; $\boldsymbol{\Delta}=$ placebolfrusemide day; $\bigcirc=$ placebo/vehicle day. 
ultrasonically nebulised distilled water ${ }^{29}$ which is thought to be mediated by prostaglandins. This result suggests that the prostaglandins released in the airways by non-isotonic aerosol challenge are inhibited by taking $100 \mathrm{mg} /$ day of oral indomethacin for three days before challenge. If inhaled frusemide $(40 \mathrm{mg})$ enhances airway prostaglandin release, causing a rise in $\mathrm{FEV}_{1}$ during hyperosmolar saline challenge, then $100 \mathrm{mg} /$ day indomethacin should at least partially inhibit prostaglandin production and reduce the rise in $\mathrm{FEV}_{1}$ during challenge.

Investigators have suggested that bronchoconstrictor prostaglandins are released during indirect airway challenges such as water and metabisulphite. ${ }^{3031}$ When these investigators gave either oral ${ }^{31}$ or inhaled ${ }^{31}$ cyclo-oxygenase inhibitors before challenge there was a significant improvement in airway sensitivity to these challenges. This improvement was enhanced in the presence of frusemide. In our study indomethacin did not improve airway sensitivity when taken before $4.5 \% \mathrm{NaCl}$ challenge or when taken in combination with inhaled frusemide. This suggests that bronchoconstricting prostaglandins are not released during challenge with $4.5 \% \mathrm{NaCl}$ or that adequate pulmonary cyclo-oxygenase inhibition was not achieved in all subjects. Our study, however, is the first to attempt to record objectively the effectiveness of cyclo-oxygenase inhibition by measuring $\mathrm{TXB}_{2}$ levels on both indomethacin and placebo days. Unlike previous studies, we have evidence to support the inhibition of prostaglandin production by indomethacin as there was a significant reduction in $\mathrm{TXB}_{2}$ levels on the days indomethacin was taken. What is uncertain is whether this dose was effective at reducing airway prostaglandin activity.

The fact that indomethacin had no effect on the transient bronchodilation observed in the presence of frusemide during $4.5 \% \mathrm{NaCl}$ challenge suggests that $\mathrm{PGE}_{2}$ was not implicated in this response. Other substances that may be involved in the transient bronchodilation observed in these studies are vasoactive intestinal peptide (VIP) and nitric oxide (NO), possible neurotransmitters released from the inhibitory non-adrenergic non-cholinergic (iNANC) nervous system in human airways. ${ }^{3233}$ The iNANC nervous system is the only known neural bronchodilator system found in the airways. A hypertonic stimulus has the potential to release sensory neuropeptides from rat trachea ${ }^{34}$ and human bronchial airways $^{35}$ and an increase in airway osmolarity causes an increase in the discharge frequency of airway sensory nerves in dogs. ${ }^{36}$ It has been shown in vitro that VIP is released from canine intestinal tissue in response to a hypertonic stimulus. ${ }^{37}$ It is therefore conceivable that a hypertonic stimulus has the potential to cause the release of VIP and/or NO.

If these neurotransmitters are released in response to a hypertonic stimulus, then why was the transient bronchodilation during $4.5 \%$ $\mathrm{NaCl}$ challenge only observed in the presence of frusemide? There may be several possible explanations. Firstly, frusemide may delay the onset of airway narrowing by initially blocking the release of mast cell mediators ${ }^{3}$ while bronchodilating mediators such as VIP and NO are being released in response to the hypertonic stimulus. As the hypertonic stimulus continues, frusemide becomes ineffective at blocking mast cell mediator release and these bronchoconstricting mediators override the bronchodilating effect of VIP and/or NO. Secondly, frusemide may block the release of neurotransmitters from the excitatory nonadrenergic non-cholinergic nervous system (eNANC) such as substance $\mathrm{P}$ which causes contraction of bronchial smooth muscle. ${ }^{38}$ With the temporary blockade of eNANC neurotransmitters the iNANC system would be unopposed and this would account for the observed transient bronchodilation. Whether frusemide preferentially blocks the eNANC nervous system is uncertain as this action of frusemide has not been studied. Thirdly, the release of VIP and NO in the presence of a hypertonic stimulus may be dependent upon blocking a frusemide sensitive chloride channel, possibly at airway sensory nerves. ${ }^{24}$ Finally, a hypertonic stimulus in combination with frusemide may stimulate the release of bronchodilating mediators from airway epithelium. Studies performed in equine trachealis muscle have shown that frusemide inhibited cholinergic nerve stimulation; however, this response was dependent on the epithelium being intact. ${ }^{39}$ More recently Verleden and colleagues ${ }^{40}$ have shown, in human bronchial tissue where the epithelium had been removed, that frusemide in combination with indomethacin was effective at inhibiting cholinergic contraction of the tissue.

In conclusion, this study shows that prostaglandins are unlikely to be responsible for the transient bronchodilation observed in the presence of frusemide during $4.5 \% \mathrm{NaCl}$ challenge in asthmatic subjects.

The authors thank Dr Jennifer Peat for her assistance with the statistical analysis and the Pharmacy department at Royal Prince Alfred Hospital, Sydney for their assistance in coding the drugs. This research was performed with funding from the $\mathrm{NH}$ and This research was perfor
MRC of Australia (LR).

1 Robuschi M, Vaghi A, Gambaro G, Spagnotto S, Bianco S Inhaled furosemide (F) is effective in preventing ultraInhaled furosemide $(\mathrm{F})$ is effective in preventing ultrasonically nebulised $5.8 \% \mathrm{NaCl}$
Respir F 1988;1(Suppl 2):S194.

2 Rodwell LT, Anderson SD, du Toit JI, Seale JP. The effect of inhaled frusemide on airway sensitivity to inhaled $4.5 \%$ sodium chloride in asthmatic subjects. Thorax 1993;48 208-13.

3 Anderson SD, Wei He, Temple DM. Inhibition by furosemide of inflammatory mediators from lung fragments. N Engl f Med 1991;324:131.

4 Barnes PJ. Diuretics and asthma. Thorax 1993;48:195-6.

5 Scherer B, Weber PC. Time-dependent changes in prostaglandin excretion in response to frusemide in man. Clin Sci 1979;56:77-81.

6 Miyanoshita A, Terada M, Endou H. Furosemide directly stimulates prostaglandin $\mathrm{E}_{2}$ production in the thick ascending limb of Henle's loop. F Pharmacol Exp Ther 1989; 251:1155-9.

7 Pavord ID, Tattersfield AE. Bronchoprotective role for endogenous prostaglandin $\mathrm{E}_{2}$. Lancet 1995;345:436-8.

8 Assouline G, Leibson V, Danon A. Stimulation of prostaglandin output from rat stomach by hypertonic solutions. Elandin output from rat stomach

9 Churchill L, Chilton FH, Resau JH, Bascom R, Hubbard WC, Proud D. Cyclooxygenase metabolism of endogenous arachidonic acid by cultured human tracheal epithelia cells. Am Rev Respir Dis 1989;140:449-59.

10 Knight DA, Stewart GA, Thompson PJ. Histamine tachyphylaxis in human airway smooth muscle. The role of $\mathrm{H}_{2}$ receptors and the bronchial epithelium. Am Rev Respir Dis 1992;146:137-40. 
11 Pavord ID, Wisniewski A, Tattersfield AE. Inhaled frusemide and exercise-induced asthma: evidence of a role for inhibitory prostanoids. Thorax 1992;47:797-800.

12 Walters EH, Bevan C, Parrish RW, Davies BH, Smith AP. Time-dependent effect of prostaglandin $\mathrm{E}_{2}$ inhalation on airway responses to bronchoconstrictor agents in normal subjects. Thorax 1982;37:438-42.

13 Higgs GA, Vane JR. Inhibition of cyclo-oxygenase and lipoxygenase. Br Med Bull 1983;39:265-70.

14 Goldman HI, Becklake MR. Respiratory function tests. Normal values at medium altitudes and the prediction of normal results. Am Rev Respir Dis 1959;79:457-67.

15 Seale JP. Analgesic-induced asthma. Med $\mathcal{F}$ Aust 1983;1: 585-7.

16 Friedman $M$, Walker S. Assessment of lung function using an airflow meter. Lancet 1975; i:310-12.

17 Thorngren $M$, Vinge E. Thromboxane $\mathrm{A}_{2}$ and prostacyclin release in bleeding time blood during primary haemostasis release in bleeding time blood during primary haemostasis

18 Flower RJ, Moncada S, Vane JR. Analgesic-antipyretics and anti-inflammatory agents; drugs employed in the treatment of gout. In: Gilman AG, Goodman LS, Roll TW, Murod F, eds. Goodman and Gilman's the pharmacological basis of therapeutics. 7th ed. London: Macmillan, 1985: 674-715.

19 Anderson SD, Smith CM, Rodwell LT, du Toit JI, Riedler $\mathrm{J}$, Robertson CF. The use of non-isotonic aerosols for evaluating bronchial hyperresponsiveness. In: Spector SL, Ed. Provocation testing in clinical practice. New York: Marcel Dekker, 1995:249-78.

20 O'Donnell WJ, Rosenberg M, Niven RW, Drazen JM, Israel E. Acetazolamide and furosemide attenuate asthma induced by hyperventilation of cold, dry air. Am Rev Respir Dis 1992;146:1518-23.

21 Mullol J, Ramis I, Prat J, Rosello-Catafau J, Xaubet A, Piera C, Gelpi E, Picardo C. Failure of frusemide to Piera C, Gelpi E, Picardo C. Failure of frusemide to increase production of prostaglandin $\mathrm{E}_{2}$ in

22 Bianco S, Vaghi A, Robuschi M, Pasargiklian M. Prevention of exercise-induced bronchoconstriction by inhaled furosemide. Lancet 1988;ii:252-5.

23 Robuschi M, Gambaro G, Spagnotto S, Vaghi A, Bianco $\mathrm{S}$. Inhaled furosemide is highly effective in preventing ultrasonically nebulised water bronchoconstriction. Pulmonary Pharmacol 1989;1:187-91.

24 Grubbe RE, Hopp R, Dave NK, Brennan B, Bewtra A, Townley R. Effect of inhaled furosemide on the bronchial response to methacholine and cold-air hyperventilation challenges. F Allergy Clin Immunol 1990;85:881-4.

25 Nichol GM, Alton EWFW, Nix A, Geddes DM, Chung $\mathrm{KF}$, Barnes PJ. Effect of inhaled furosemide on metabisulfite- and methacholine-induced bronchoconstriction and nasal potential difference in asthmatic subjects. $A m$ Rev Respir Dis 1990;142:576-80.
26 Moscato G, Dellabianca A, Falagiani P, Mistrello G, Rossi $G$, Rampulla C. Inhaled furosemide prevents both the bronchoconstriction and the increase in neutrophil chemotactic activity induced by ultrasonic "fog" of distilled water in asthmatics. Am Rev Respir Dis 1991;143:561-6.

27 Feather IR, Olson LG. Frusemide antagonises exerciseinduced but not histamine-induced bronchospasm. Aust NZ F Med 1991;21:7-10.

28 Karpel JP, Dworkin F, Hager D, Feliciano S, Shapiro D, Posner L, Luks D. Inhaled furosemide is not effective in acute asthma. Chest 1994;106:1396-400.

29 Mattoli S, Foresi A, Corbo GM, et al. The effect of indomethacin on the refractory period occurring after the inhalation of ultrasonically nebulized distilled water. $f$ Allergy Clin Immunol 1987;79:678-83.

30 Bianco S, Vaghi A, Pieroni MG, Robuschi M, Refini RM, Berni F, et al. Potentiation of the anti reactive, antiasthmatic effect of inhaled furosemide by inhaled lysine acetylsalicylate. Allergy 1993;48;570-5.

31 O'Connor BJ, Barnes PJ, Chung KF. Inhibition of sodium metabisulphite induced bronchoconstriction by frusemide in asthma: role of cyclo-oxygenase products. Thorax 1994, 49:307-11.

32 Palmer J, Cuss F, Barnes P. VIP and PMH and their role in nonadrenergic responses in isolated human airways. $f$ Appl Physiol 1986;61:1322-8.

33 Belvisi MG, Stretton CD, Yacoub M, Barnes PJ. Nitric oxide is the endogenous neurotransmitter of bronchodilator nerves in humans. Eur 7 Pharmacol 1992;210: $221-2$

34 Umeno E, McDonald DM, Nadel JA. Hypertonic saline increases vascular permeability in the rat trachea by producing neurogenic inflammation. 7 Clin Invest 1990;85: 1905-8.

35 Jongejan RC, de Jongste JC, Raatgeep HC, Stijnen T, Bonta IL, Kerrebijn KF. Effect of hyperosmolarity on isolated central airways. Br $\mathcal{f}$ Pharmacol 1991;102:931-7.

36 Pissari TE, Jonzon A, Coleridge HM, Coleridge JCG. Vagal afferent and reflex responses to changes in surface osmolarity in lower airways of dogs. F Appl Physiol 1992;73 2305-13.

37 Ebeid AM, Soeters PB, Murray P, Fischer JE. Release of vasoactive intestinal peptide (VIP) by intraluminal osmotic stimuli. F Surg Res 1977;23:25-30.

38 Lundberg JM, Martling CR, Saria A. Substance P and capsaicin-induced contraction of human bronchi. Acta Physiol Scand 1983;119:49-53.

39 Yu M, Wang Z, Robinson NE, Derksen FJ. The inhibitory effect of furosemide on the contractile response of equine trachealis to cholinergic nerve stimulation. Pulmon Phar macol 1992;5:233-8.

40 Verleden GM, Pype JL, Deneffe G, Demedts MG. Effect of loop diuretics on cholinergic neurotransmission in human airways in vitro. Thorax 1994;49:657-63. 